Article

\title{
Lessons from Participatory Evaluation of Cropping Practices in Yunnan Province, China: Overview of the Effectiveness of Technologies and Issues Related to Technology Adoption
}

\author{
Madhu Subedi ${ }^{1} *$, Trevor J. Hocking ${ }^{1}$, Michael A. Fullen ${ }^{1}$, Alison R. McCrea ${ }^{1}$ and \\ Eleanor Milne ${ }^{2}$
}

1 School of Applied Sciences, The University of Wolverhampton, Wulfruna Street, Wolverhampton WV1 1LY, UK; E-Mails: T.J.Hocking@wlv.ac.uk (T.J.H.); M.Fullen@wlv.ac.uk (M.A.F.); A.R.Mccrea@wlv.ac.uk (A.R.M.)

2 Department of Geography, University of Leicester, Leicester LE1 7RH, UK; E-Mail: em192@1e.ac.uk

* Author to whom correspondence should be addressed; E-Mail: M.Subedi@wlv.ac.uk; Tel.: +44-1902-322270; Fax: +44-1902-322714.

Received: 9 August 2009 / Accepted: 9 September 2009 / Published: 16 September 2009

\begin{abstract}
Increasing crop production, while maintaining sustainability, is a priority for agricultural development projects, particularly in developing countries. This study investigated the factors contributing to the effectiveness of agricultural development projects in improving the sustainability of cropping systems in a small upland watershed in south-west China. This involved a review of recent related projects and detailed evaluation of one project: the SHASEA Project. Farmers' perceptions of several agricultural technologies are discussed, along with factors contributing to farmers' adoption of these technologies. Local, national and international institutions need to adopt several strategies to improve project effectiveness and agro-environmental sustainability.
\end{abstract}

Keywords: sustainable agriculture; technological effectiveness; technology adoption/ adaptation 
"Nothing great is suddenly created, any more than a bunch of grapes or a fig.

If you tell me that you desire a fig,

I answer there must be time.

Let it first blossom, then bear fruit, then ripen"

(Epictetus, 341-271 BC).

\section{Introduction}

In many parts of the developing world over the past five decades, increasing agricultural production has been the highest priority of agricultural development projects. Until the 1970s, the emphasis was on achieving higher agricultural productivity, with little regard for sustainability [1,2]. The concept of sustainability only emerged during the early 1980s [3-6]. Consequently, development activities in the early years focused on increasing production through intensification of cropping systems without due attention to resultant effects on natural resources. Consequently, large areas of the world are now facing problems of soil degradation [7], water erosion, groundwater pollution and natural resource depletion and the sustainability of many current agricultural systems is questionable [8-10]. This situation is more apparent in poor and developing countries, which depend more on agriculture for their income. For example, the sloping highlands of South-East Asia have witnessed considerable pressure due to water erosion, land degradation and low farm productivity [11-15]. The problems associated with intensification are more serious in China than most other countries in the World [16] and present enormous challenges for the future.

In Yunnan Province, most cultivable land is suffering soil erosion and thus contributing to sediment loading of the Yangtze River and hence downstream flooding [17]. Similarly, crop yields on sloping land in South China have decreased by $30-60 \%$ because of soil erosion [18]. It has been predicted that most topsoil will disappear within the next 100 years if current erosion rates continue [19]. Thus, more effective soil and water conservation, while maintaining or increasing productivity, have become essential goals if agriculture is to be sustained on sloping land in these highland areas. In this context, the SHASEA (Sustainable Highland Agriculture in South-East Asia) Project investigated more holistic approaches for the development and evaluation of agronomic and soil conservation measures, designed to improve the productivity and sustainability of cropping systems at a field scale. The purpose of this paper is to share the experience of conducting participatory evaluation and discuss issues related to technology adoption in the Chinese context.

\subsection{Background to the SHASEA Project}

The SHASEA (Sustainable Highland Agriculture in S.E. Asia) Project (European Union (EU) Contract Number: ERBIC18CT980326) focused primarily on Yunnan Province, with a secondary site in North Thailand. The aim was to improve agricultural productivity and sustainability of cropping systems in highland regions of South-East Asia. This program had the specific objectives of implementing and evaluating practices to increase the productivity of corn, wheat and soybean on fragile slopes in a sustainable and environmentally-friendly way. The approach incorporated modified and novel agronomic and soil conservation measures, evaluating the agricultural, environmental and socio-economic impacts of these measures using multidisciplinary approaches. This EU-funded 
INCO-DEV project involved a collaborative research team from Belgium, Ireland, the U.K., China and Thailand. A longer-term aim was to use the modified cropping systems developed in a watershed north of Kunming as a demonstration area and training model for sustainable agricultural development in the South China highlands (Figure 1). A parallel study, restricted to scientific evaluation of agronomic and physico-chemical impacts, was carried out in plot studies at Pangmapa, in the highlands of North Thailand, testing the broader applicability of the cropping practices being developed for S.E. Asia.

Figure 1. Map of Yunnan Province, China.

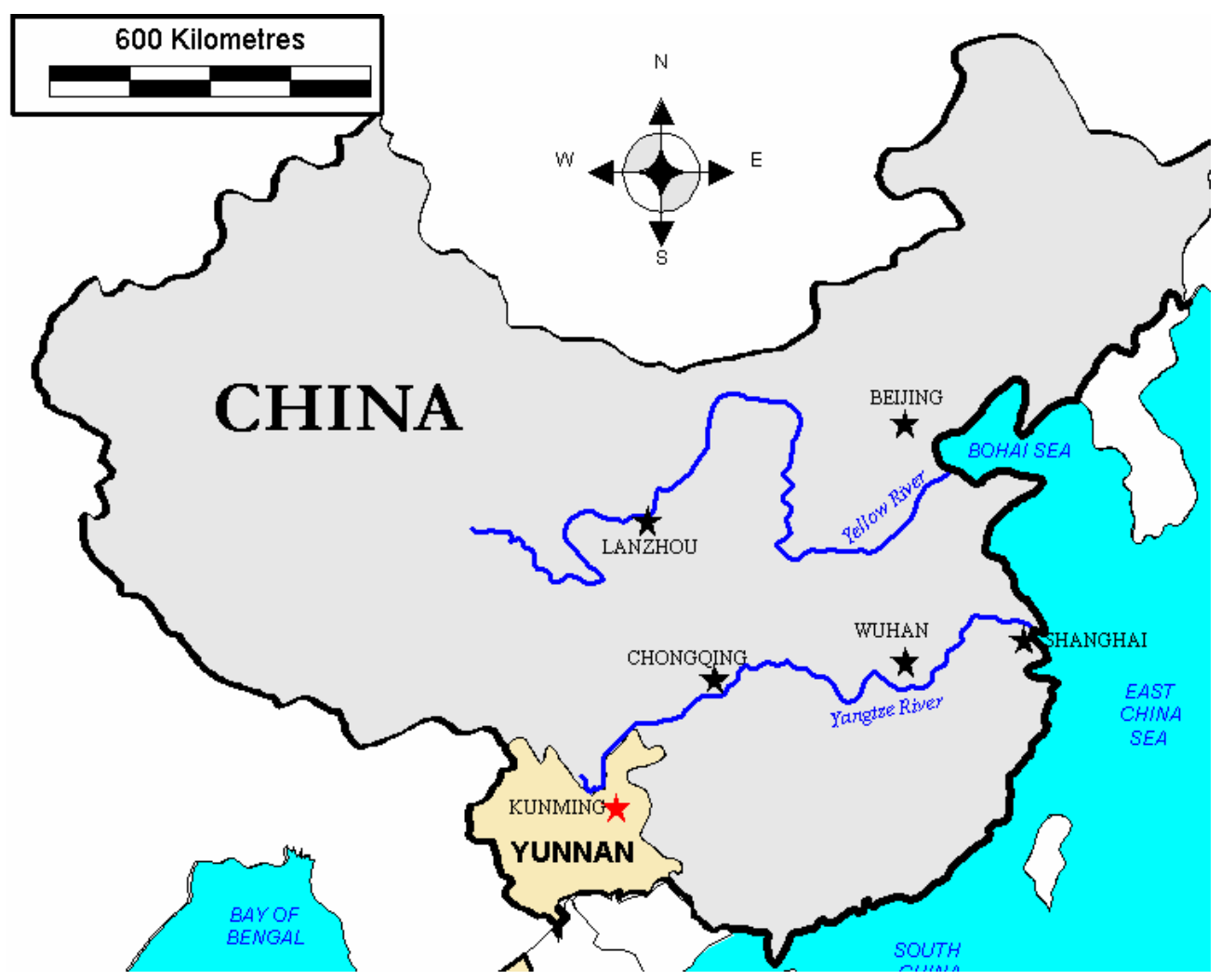

The SHASEA Project was implemented in Wang Jia watershed in Kelang village in Yunnan Province, China. The SHASEA Project adopted a holistic and multidisciplinary approach to implement project activities. The basic research was conducted in a field research station and applied research under farmers' field conditions [20]. Thus, the innovation system of SHASEA Project was similar to the FSR/E approach and Model I of FPR approach [21]. Most cultivable land in Kelang village was located on sloping uplands $(\sim 80 \%)$, where fairly intensive cultivation was practiced [22]. Soil erosion from the cultivated land was a common problem. In this context, Kelang village was selected as the Project site.

\subsection{Socio-Economic Situation of Wang Jia Watershed, Kelang Village}

Kelang village is quite an old establishment. The village has most of the basic development infrastructure, such as road links to other cities and towns, a hospital, a school, water supply, electricity, telephone, market and some government offices. 
From a geomorphopedological perspective, Wang Jia represents a typical upland watershed and from the socio-economic perspective Kelang village was considered a fairly typical rural village in Yunnan Province [12]. Subsequently it was found that, unlike in other villages in the locality, the dependence on agriculture for household income in Kelang village was decreasing and the livelihood strategy of the farming household was shifting from on-farm to off-farm activities. This change in livelihood strategy was possible because of good opportunities for off-farm employment both in Kelang and Kunming, the nearest major city [20]. Few villages have the same level of off-farm employment opportunities. So despite the initial perception of being one of the typical rural villages of Yunnan, Kelang may not be as representative as was first believed and this may pose limitations on generalizations that can be drawn for the surrounding region. Enthusiasm and commitment of the households to farming may be an important factor for the adoption of more sustainable cropping practices.

\subsection{The Project Site: Wang Jia Watershed}

The SHASEA Project was implemented in the Wang Jia Watershed of Kelang village within Kedu Township in Xun Dian County, north-east Yunnan $\left(25^{\circ} 28^{\prime} \mathrm{N}, 102^{\circ} 53^{\prime} \mathrm{E}\right)$. The altitude of the watershed ranges between 2,044 and 2,191 m asl. The total area is 40.1 ha, of which 27.3 ha of sloping uplands is suitable for cultivation, 1.1 ha is covered by sweet chestnut trees, 0.4 ha by rocky land, 9.5 ha by forest trees and 1.8 ha by barren hills [23]. The upper watershed is covered by forest. Sweet chestnut has been planted on the lower elevation of the forest. The cultivated area is located in the lower areas. There is a spring at the upper part of the watershed, which has a small perennial discharge. The climate falls under the sub-tropical monsoon climatic zone, with a mean annual rainfall of $1043 \mathrm{~mm}$. The distribution of rainfall is uneven. Most ( 80\%) rain falls between June and October, with a dry period between November and May (a period of moisture stress for winter crops). The average temperature is $15^{\circ} \mathrm{C}$, and 122 days in the winter are frost prone (243 days frost-free). The average annual sunshine is 2,082 hours.

\section{Effectiveness of the SHASEA Project in Relation to Its Own Scientific Objectives}

The SHASEA Project was implemented at a watershed scale with the twin objectives of: (i) increasing productivity and (ii) achieving this in a more sustainable and environmental-friendly way [24]. INCOPLAST (Integrated Contour Cultivation, Polythene and Straw Mulch Treatment), was designed as an innovative practice to achieve both objectives (increase productivity and sustainability). The latter was also addressed through additional measures at watershed level. In all, seven agricultural technologies and development interventions were tested/introduced (Table 1), together with several engineering measures.

There was a good mixture of researchers and development agents in the Project team from local and European organizations. As far as the Project team was concerned, the farmers did what was required and their participation in the SHASEA Project was limited to consultation and participation in training and field days. The 1990s decade witnessed a shift in the working approach of development assistance organizations from the top-down approach to a participatory process [25]. However, farmer participation in the SHASEA Project was not robust. There were extensive discussions with village 
and township leaders. However, effective communication between local and foreign partners was limited by language barriers. Agricultural systems that involve farmers in experimentation and evaluation are more progressive than those which prescribe instructions [26].

Table 1. Agricultural technologies/development interventions tested and extended in Wang Jia Watershed, 2002.

\begin{tabular}{|c|c|c|}
\hline No. & echnologies & Remarks \\
\hline 1 & $\begin{array}{l}\text { Polythene } \\
\text { mulching }\end{array}$ & $\begin{array}{l}\text { Existing technology: but mostly used in tobacco and vegetable } \\
\text { production. The Project tested and extended this technology in order } \\
\text { to reduce soil erosion and increase corn productivity. }\end{array}$ \\
\hline 2 & $\begin{array}{l}\text { Straw } \\
\text { mulching }\end{array}$ & $\begin{array}{l}\text { Technology new to the area: The Project tested and extended this } \\
\text { technology to increase soil quality and corn productivity and reduce } \\
\text { soil erosion. }\end{array}$ \\
\hline 3 & Irrigation & $\begin{array}{l}\text { Existing technology: but with very low access, particularly in } \\
\text { upland areas. The Project tested and extended this technology to } \\
\text { increase crop productivity, extend the cropping season during } \\
\text { drought periods and reduce crop failure during droughts. }\end{array}$ \\
\hline 4 & $\begin{array}{l}\text { Contour } \\
\text { cultivation }\end{array}$ & $\begin{array}{l}\text { Existing technology: but not widely practiced, as traditionally } \\
\text { farmers have cultivated using downslope cultivation. The Project } \\
\text { tested and extended this technology in order to reduce runoff and } \\
\text { soil erosion and thereby conserve soil resources, thus preventing } \\
\text { productivity decline. }\end{array}$ \\
\hline 5 & jing & $\begin{array}{l}\text { Existing technology: but adapted by farmers to suit their conditions } \\
\text { and needs, which were different to the recommended intercropping } \\
\text { practice. The Project tested and extended improved intercropping } \\
\text { technology to increase overall crop productivity and economic } \\
\text { return. }\end{array}$ \\
\hline 6 & $\begin{array}{l}\text { Use of grass } \\
\text { strips }\end{array}$ & $\begin{array}{l}\text { Technology new to the area: The Project tested and extended this } \\
\text { technology on a small scale to reduce runoff and soil erosion and } \\
\text { increase organic matter inputs. }\end{array}$ \\
\hline 7 & Tree planting & $\begin{array}{l}\text { Existing technology: The Project extended this activity as an } \\
\text { ecologically and economically suitable alternative in sloping areas } \\
\text { where the gradient is }>25^{\circ}(47 \%) \text {. }\end{array}$ \\
\hline
\end{tabular}

The Project was successful in achieving its stated scientific and technical objectives. In summary, the successful outcomes were:

- Novel and modified cropping practices have been evaluated, including INCOPLAST, which can increase corn yield by $\leq 50 \%$, compared to traditional methods.

- Land management plans have been developed to achieve more sustainable agricultural systems in Wang Jia. 
- Comprehensive surveys and descriptions of the biophysical characteristics of the watershed have been completed, which have provided a baseline for subsequent change and established the representativity of the watershed in relation to surrounding areas.

- Socio-economic analysis determined the economic and social feasibility of the alternative cropping strategies, the wider implications of the land use changes and the likelihood of subsequent adoption and adaptation of the technologies employed. Moderately long (five years plus) perspectives are needed for investment programs to yield dividends.

- Scientific evaluation of selected cropping practices developed in Wang Jia has been carried out in North Thailand and has demonstrated that these practices are generally as effective as the best practices in use in that region [12].

- Dissemination and training activities for wider adoption of these practices and associated recommendations have been initiated.

- Scientific training associated with the project outcomes has been achieved through a series of undergraduate, Masters and Ph.D. programs.

- Dissemination of scientific outcomes has been achieved through presentations at several national and international conferences, a scientific tour of the watershed, a provincial workshop held at Yunnan Agricultural University (YAU) and publications and reports.

Initial uptake was monitored by the Project team in the final year of the Project. There was comparatively high initial uptake of polythene mulch, contour cultivation, sweet chestnut and intercropping technologies in Wang Jia during the first year after Project intervention. Polythene mulch for corn was used in more areas in the watershed compared with neighboring areas. Similarly, the use of contour ridges was greater in the watershed than surrounding areas. The longer-term actual contribution of these technical achievements to improved productivity and sustainability depends on the extent of future adoption/adaptation of these technologies by farmers. Farmers' attitudes towards a technology strongly influence whether they intend to adopt it [27]. Farmers' perceptions and their future intentions about the adoption of project technologies are important to translate scientific demonstration of effectiveness into increased productivity, higher household incomes and improved conservation and sustainability. Planning and implementation of an adaptive project is completed in four phases (experimental, pilot, demonstration and replication projects) to address the problem in experimental, incremental and adaptive ways [28]. The SHASEA Project, however, completed only the first two phases. Farmers' perspectives and their views on the adoption/adaptation of the practices introduced by the Project are discussed in the following sections.

\section{Effectiveness of SHASEA Project Technologies as Perceived by Farmers and Stakeholders at Project Completion}

\subsection{Contour Cultivation}

Farmers perceived contour cultivation as one of the most preferred and appropriate technologies for Wang Jia, evidenced by a high proportion of farmers (in household interviews and discussions with groups and Key Informants) who adopted contour cultivation [29]. Farmers perceived that the area under downslope cultivation diminished over time and the area under contour cultivation practices 
increased. Downslope cultivation was considered easier, less time-consuming and thus required less labor compared to contour cultivation.

Contour cultivation was perceived to be easier than downslope cultivation for irrigation, fertilization and harvesting. However, downslope cultivation was perceived to be easier than contour cultivation for weed control, earthing up, covering polythene and draining excess water from the field [30]. Furthermore, contour cultivation was perceived to have more favorable effects on production compared to downslope cultivation, as soil, water and nutrient losses were believed to be higher in downslope cultivation resulting in inferior crop performance and crop yields. Several published works reported similar results [11,31-37]. High weed population and increased tendency of lodging were the only perceived disadvantage of contour cultivation. Considering the popularity of traditional downslope cultivation in Yunnan, adoption of contour cultivation technology will be more widespread only after considerable efforts on the dissemination of the technology or ways to be found to convince farmers of its importance in reducing soil losses. Various authors have stressed the need for more access to information for farmers, more dissemination activities and demonstration of clear benefits from technologies in order to improve farmers' uptake and adoption of soil and water conservation technologies [38-40].

\subsection{Mulching}

Two types of mulching technologies (polythene mulch and straw mulch) were evaluated in Wang Jia. Farmers preferred polythene mulch as they perceived that it improves seedling emergence, increases crop production and conserves soil, water and soil fertility [30]. Insufficient soil moisture during winter, spring and early summer season often results in poor crop establishment in south-west China [41]. Polythene mulch conserves soil moisture by reducing evaporation losses, particularly during the dry season [42,43 as cited by 44]. In addition, polythene mulch increases soil temperature during early spring and winter, when soil temperatures are usually low $[44,45]$. Thus use of polythene mulch favors early crop establishment and increased crop yield [17,44,45]. This could be the reason why farmers perceived 'improvement in seedling emergence' and 'increase in crop production' as the most important advantages of polythene mulching. Farmers, however, wanted to use polythene mulch particularly for high value crops, which ensure higher returns for the purchased polythene. So, despite the high preference of farmers, it may be unrealistic to expect significant adoption of polythene mulch for corn. Moreover, the adoption of polythene mulch could be limited among poorer farmers because of the cost associated with this technology.

Straw mulch did not appear as a farmer-preferred technology. Initial uptake of straw mulch technology by farmers was low. Use of straw mulch increased corn yield, retained soil moisture and reduced moisture losses from soil during drier periods [44,46-49]. Farmers were aware of the advantages of straw mulch technology. However, low uptake was mainly due to the low availability of straw for mulching. Farmers preferred to use straw for feeding livestock, so it is less likely that farmers will use straw for mulching until production exceeds their requirements for animal feed. Nonavailability of material inputs is one of the frequently quoted reasons for low uptake [50]. Similarly, Brown [51] argued that extent of innovation diffusion depends on the availability of innovation technologies. Any future endeavor in promoting straw mulch in this area must consider increasing 
straw production. Straw mulching was not a traditional practice for farmers in this area and farmers were unenthusiastic about increasing the area under straw mulch.

Cost-benefit analysis of mulching revealed, however, that polythene and polythene + straw mulching were both economically profitable options for corn. The net income from both of these mulching options exceeded no mulching, by 945 Yuan/ha ( $\$ 1=6.82$ Yuan (¥), August 2009) [30].

\subsection{Intercropping}

Farmers in Wang Jia practiced intercropping in a traditional way by mixing low density companion crops within the main crop. However, the area under the recommended intercropping practice was very small [29]. Farmers were reluctant to use these alternative intercropping practices. The soybean variety introduced by the Project team for intercropping failed to produce pods and hence grain yield in one season, so it may have been unsuitable for Wang Jia. This could be the reason for farmers' reluctance to use this particular practice, although cost-benefit analysis of intercropping revealed that corn/French bean intercropping was more profitable than monoculture corn by $735 \mathrm{Yuan} / \mathrm{ha}$ [30]. Clear effectiveness of the potential technology is one of the important conditions for the uptake and adoption of technologies by farmers [39,52]. Similarly, Garforth and Usher [53] reported that appropriateness was the most commonly cited factor for the uptake of research outputs.

\subsection{Tree planting}

The tree planting strategy complied with Government policy and took advantage of the export potential of the selected tree products. Land with $>25^{\circ}$ (47\%) slope angle was selected for planting, consistent with Government policy [36,54,55]. Planting sweet chestnut in the lower part of the watershed and prickly ash in the upper part were profitable income generating options for farmers. The different locations took into account the differing eco-environmental requirements.

Farmers liked both the tree planting strategy and the species selected for planting in Wang Jia. However, despite their preferences, farmers were reluctant to adopt the technology due to their small land holdings and competition between trees and crops resulting in low crop yields before any income benefits materialized [30]. Farmers preferred those technologies that gave quick returns, or met family food requirements. Farmers were concerned about the long-term nature of investment in tree planting. Moreover, the initial six years would be difficult for the poorer sections of the village (Figure 2). Thus any expectation of wide adoption of tree planting by smallholders would be unrealistic, unless the treeplanting program is accompanied by either subsidy provision for the initial six years, or suitable rapid income-generating options. Adoption is more likely among richer farmers, who have good economic buffering capacity. In Nepal, small landholders were hesitant to accept new technologies which take time to produce returns, despite their potential to earn higher income than the existing practices over longer time periods [52]. 
Figure 2. Short-term comparative annual income (in terms of Net Present Value) Yuan/ha/year from annual crops, sweet chestnut (SC) and prickly ash (PA), Yunnan Province, China, 2002-03 [30]. \$1 = 6.82 Yuan (¥) August 2009.

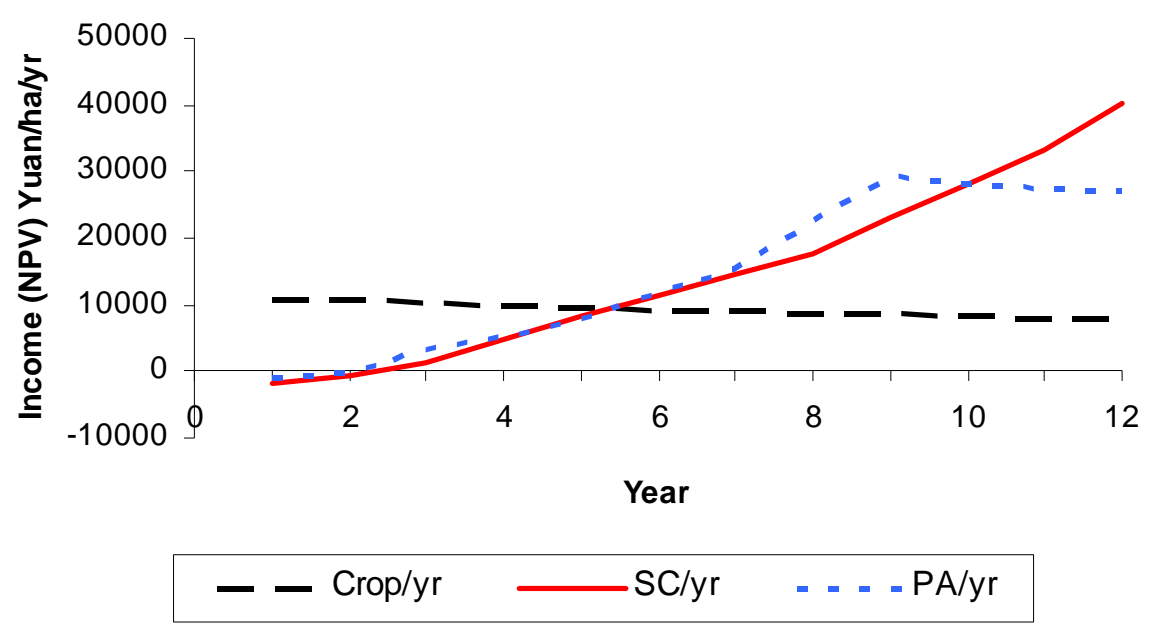

The tree planting strategy was developed by the township and village Leaders. All decisions regarding the plantation area and tree species were taken by local researchers and township/village leaders. Farmers were not involved in the decision-making process. However, addressing poverty using agro-forestry interventions is not possible just by considering biophysical issues. The effects on soil fertility and rural livelihoods are mediated by socio-economic factors [56]. The socio-economic factors and farmers' concerns could have been better addressed if farmers had been involved in the process.

\subsection{Irrigation}

Considering the capacity of the system, the use of irrigation was low in terms of both number of users and area irrigated [30]. There was a need for the irrigation system, local leaders were committed to the scheme, field trials established the benefits of using irrigation, but despite all these positive attributes, many farmers did not use irrigation. A possible reason could be the cost, which was more than the anticipated benefit from production [57]. Farmers in upland areas of Yunnan either use polythene pipes or carry the water on their shoulders to irrigate fields, which is difficult and costly, particularly for field crops. Contrary to this finding, small-scale irrigation schemes have been more successful in other regions, for example in tropical Africa [58].

Farmers said they were willing to contribute to the future maintenance, management and use of the irrigation system. However, these responses did not accord with their current practice. This was probably because they were anticipating future changes in cropping systems. They considered that corn might be replaced by income-generating crops, such as tobacco, vegetables, flowers and fruit trees. This indicates that farmers did not want to use extra resources in irrigating low value, high volume crops, such as corn and wheat, but wanted to have irrigation available for more profitable high value crops in the future. Since the project objectives were to use irrigation to increase productivities of corn and wheat, this approach was unsuccessful in the watershed as a whole. 


\section{Effectiveness of Training and Dissemination Activities of the Project}

Training activities were conducted primarily for farmers within the Project area. The Project did not implement gender or wealth-differentiated training programs. Most farmers across the gender and wealth categories had access to the training programs [29]. Training activities were organized twice a year (once during the corn growing season and another during the wheat growing season). This would have been more effective if short training sessions had been organized at different times of the season when particular technologies could be used in the farm in real life situations. Training based on real life materials and situations has been described as an effective means of training delivery [59].

Examples were found which indicated that there was a need for more training. Farmers were found to adopt technologies inappropriately in Wang Jia and its vicinity. For example;

a. A farmer in Wang Jia planted prickly ash trees at a very high density (five times more than recommended). In addition, he planted sweet chestnut trees in the gap between two rows. The trees were planted at different times, so the trees were at different growth stages. At first, the farmer planted few trees and found it to be more profitable. Then he planted more trees in the same land exceeding the recommended density many fold.

b. A farmer from nearby Mosu village planted sweet chestnut trees at very high density (three times higher than recommended). He was unaware of the improved management technology, so a very poor yield is likely, resulting in economic setback.

c. The practice of most farmers for disposing of used polythene was potentially environmentally hazardous. Scope for recycling already existed in Kelang village, as some local merchants were buying used polythene. Farmers' awareness needed to be increased through training and demonstrations, in order to promote the recycling of used polythene.

Inappropriate adoption of technologies by farmers could be because of poor knowledge and information resulting from insufficient extension and training services provided to farmers. Whatever the reasons, the benefit from the technology could not be expected when it was adopted incorrectly. The failure of improved technologies to be technically effective and economically profitable in their hands is likely to result in farmers stopping their use of the technology. So there is a need for more training of farmers in project technologies. Training played important roles in the transfer of sustainable soil management technologies to wider communities in Nepal [52].

Dissemination helps increase the level and speed of uptake of research outcomes by farmers [50]. Project information was well disseminated within the scientific community via workshops and the publication of Project information in books, proceedings, posters and pamphlets [20]. However, Project plans were not explicit in describing how wider dissemination at farmer-level would be achieved.

Information about Project activities was disseminated well within Wang Jia watershed only. This was achieved by increasing farmers' awareness through training, and by providing material help/ compensation to encourage initial adoption [30]. All farmers in the watershed had some information about Project activities and status. Medium and rich categories were more aware than poor category households. Wider dissemination of Project activities outside the watershed and associated training was insufficient during the first phase of the Project. Further dissemination was planned for the second phase of the Project, which was proposed to the EU INCO-DEV Program, but did not receive funding. 
The SHASEA Project was one of the most important sources of information for improved agricultural technologies during the Project period in Kelang village. Farmers also received information about improved agricultural technologies from neighbors and relatives. Garforth et al. [60] mentioned that 'other farmers' was the most frequently reported source in most survey reports, where sources of information were asked of farmers. Similarly, Subedi and Garforth [61] argued that farmerto-farmer diffusion of innovations is important, irrespective of any formal extension intervention. Farmers are more likely to be influenced by other farmers than by extension professionals for their farming practices and management decisions [53]. For example, farmers in Nepal considered information from friends, relatives and neighbors to be the most trustworthy source for learning about new innovations [52]. This highlights the importance of the farmers' role in information dissemination, which underpins the relevance of strengthening farmer-to-farmer extension systems in the area.

There was inadequate communication between Project researchers and local extension systems regarding dissemination of Project technologies. Project researchers were unaware whether the extension services had included any Project technologies for dissemination in wider areas. Similarly, policy makers had limited information about the Project. This revealed inadequate communication between project officials and policy makers at provincial level. This would not have been the case if there had been regular contact and communication between concerned stakeholders. Information is not simply passed on but can be continually transformed and adapted through these communication networks [53].

After a general briefing about the Project, the Manager of the Soil and Water Conservation Department of Yunnan Province appreciated the Project processes (such as multidisciplinary and holistic approaches, involving farmers in Project activities), technologies and application of scientific approaches (such as installation of a gauging station) to tackle the problem of soil and water erosion in the region. Perhaps wider dissemination of Project technologies through Government extension networks and any policy impacts would have been greater if the team had established regular communications with such networks. Dissemination tends to be more complex than just technology generation and verification, because it involves more stakeholders. Thus, a multi-partnership approach, with a central role for farmers, was a more suitable approach for technology dissemination to farmers in Nepal [62].

Discussion with farmers revealed that the use of some technologies was influenced by crop type. Irrigation was more widely used for tobacco than for corn. This was because of the relatively higher return from tobacco. Similarly, downslope cultivation was preferred where tobacco was grown in order to drain excess moisture quickly, because of the susceptibility of tobacco to damage by high moisture conditions. Similarly, some technologies, particularly polythene mulch and irrigation, were more popular among farmers outside the watershed compared with those within the watershed. This was because corn was grown as the main crop in the watershed, while tobacco was grown in large areas outside the watershed. Such variation in production environments requires a 'basket of technologies' suitable for different production niches. There is increasing realization of the value of niche-based on-farm approaches to technology development and dissemination with varied levels of farmer participation in the program [63-65]. 


\section{Overall Perceptions of Stakeholders}

Local stakeholders (Leader of Kelang village and extension agents from Kedu Township) mentioned the following points as project strengths. It is obvious that some points are based on future expectations, as some effects of Project activities had not been fully realized. However, this gives some insights to what local stakeholders perceived as important and can be the starting point for planning similar projects.

a. The Project changed farmers' perceptions about natural resource management and utilization. Farmers understood the benefit of conserving natural resources, which reduced over-reliance and over-use of forest resources. Deforestation had decreased and farmers had now started to plant trees for themselves. They were now aware of the benefits of soil and water conservation and trying to avoid using technologies that lead to increased soil and water losses.

b. The check-dam in the gully was very effective in controlling soil and water losses and flood frequency and severity in the village.

c. Environmental conditions in the watershed had changed substantially due to Project efforts during the previous three years, particularly due to decreased soil-water losses and flood frequency.

d. The Project had introduced scientific technologies and training programs to farmers about improved cultivation practices. In the past, farmers used to practice downslope cultivation over large areas in the watershed. Now farmers knew the benefits of contour cultivation and the area under contour cultivation was increasing.

e. Crop productivity in the watershed had increased. The Project mobilized farmers to try improved technologies and consequently farmers were allocating more time to farming activities and investing more inputs, particularly manure and fertilizers. Consequently, crop productivity had increased.

f. Kedu Township was planning to extend some Project technologies to similar areas. In particular, the following technologies were being considered for inclusion in extension programs:

- Grass strip technology.

- Tree planting on land with $>25^{\circ}$ slope (this is also one of the strategies of the Chinese Government to address the problem of soil and water erosion in highlands).

- Contour cultivation technology.

- Polythene mulch technology.

- Construction of dams in gullies within similar watersheds.

On the negative side, the Leader of Kelang village mentioned there were too many surveys and too many questions asked by Project staff. Often the same questions were asked repeatedly. This demanded substantial time of both farmers and researchers and should have been reduced.

Suggestions were sought from different stakeholders, particularly the Key Informants, Leader of Kelang village, extension agents from Kedu Township and policy-makers from the Provincial authority. Stakeholders pointed out three major issues that needed to be considered in future research and development interventions. 
a. It would be better not to plan and implement long-term initiatives if the Project duration was short. Most stakeholders were concerned about possible damage to the rehabilitating environment, particularly the growing trees. Alternatively a clear plan should be developed for protecting such features after Project completion, which might include the provision of financial resources.

b. The stakeholders identified the need for wider dissemination of Project technologies. They also pointed out the need for extension materials, such as pamphlets, posters and radio programs, in order to achieve wider adoption.

c. Similarly, stakeholders pointed out the lack of training opportunities for farmers outside the watershed.

\section{Impacts}

\subsection{Environmental Impact of Project Activities}

Farmers appreciated the Project's activities aimed at increasing forest, water resources and soil fertility, and decreasing soil and water losses [66]. They presented several reasons for the beneficial changes in environmental conditions in the watershed. This indicates that they were aware of the benefits of Project activities, although the magnitude of the changes perceived by farmers was greater than anticipated by the Project team. Similarly, farmers in India also appreciated soil and water conservation projects, implemented in Gujarat, Rajasthan and Madhya Pradesh, for favorable impacts on crop productivity and cropping systems, soil erosion and the environment and socio-economic concerns [67].

Farmers' existing practices for the control of runoff and soil loss were similar to the Project's improved practice. The farmers' practice, however, relied more upon locally available resources (such as wood, stone and sand) to implement smaller actions at plot level, which was different to the Project's approach, which used purchased materials (such as cement and steel) to implement largescale activities at watershed level. A study conducted in Thailand reported that farmers' soil and water conservation practices were similar to those of the improved technologies introduced by development agencies and farmers were familiar with the concepts of those technologies [68].

Despite considerable use of polythene mulch, farmers were less aware of the environmental pollution due to polythene, particularly when not collected and disposed of properly after use. Some farmers collected the polythene used mainly in tobacco production and sold it to a local merchant in Kelang village. Little polythene used in corn production was recycled, due to difficulties in collecting from the field and cleaning the polythene. Studies showed that if the polythene mulch was used for three years, $\sim 37.5 \mathrm{~kg} / \mathrm{ha}$ of polythene would accumulate in the soil. Accumulation of polythene in the soil at $45 \mathrm{~kg} / \mathrm{ha}$, decreased vegetable yields by $2-10 \%$, which could be due to negative effects on plant rooting and soil water dynamics [69]. The accumulation of polythene in farmland has been termed 'white pollution' in China [42,57,70]. The SHASEA Project's effort to reduce 'white pollution' was not sufficiently effective. Two-thirds of Wang Jia farmers were still practicing environmentally hazardous methods for post-use collection and disposal of polythene from farmland. This indicates that there is a need for identifying more effective training methods for increasing farmers' awareness of 'white pollution' and motivating them to practice environmentally-friendly methods to minimize the 
negative effects of polythene accumulation on farmland. This aspect needs to be taken into consideration in the future, while designing programs for the dissemination of SHASEA results. In addition, any endeavor to extrapolate the result of polythene mulch technology must consider this aspect and design the program in order to minimize the hazardous effects of polythene on farming systems.

\subsection{Stakeholders' Perceptions on the Effects on Environmental Conditions within the Watershed}

Farmers concluded that the environmental condition of Wang Jia was better than the adjacent Lai $\mathrm{Zi}$ watershed [66]. The overall responses of the farmers focused on five major aspects, viz. (a) current situation of soil and water losses, (b) vegetation cover and natural resources, (c) infrastructures and watershed management, (d) use of environmentally-friendly technologies, and (e) crop performance and productivity. The involvement of local user groups in the monitoring and evaluation of spatial and temporal changes in the watershed can be beneficial to both local users and researchers. For local users, it may help improve "land literacy" (the ability to identify and appreciate good/poor conditions) concerning the watershed; and for researchers it would provide less expensive and rapid information about complex natural resource management issues compared to conventional approaches, requiring large and expensive datasets [71].

The farmers of Kelang village were highly capable of evaluating environmental changes in the watershed using scientific indicators. This indicates their potential to work in collaborative ventures for soil conservation and watershed improvement. However, they were very reluctant to identify Project weaknesses, and very reserved and hesitant to provide criticisms. Farmers could not envisage the importance of their responses and hence did not articulate their responses for their own benefit. This was because farmers in China are accustomed to the 'top-down' approach of the Government and there was no training and orientation program in participatory approaches designed for farmers in the Project. So, any such research and development program should start with an orientation on participatory approaches, in order to solicit meaningful contributions from farmers.

The leaders of Kelang village mentioned that the gully check-dam was very effective in controlling soil and water losses, consequently the frequency and severity of flooding had been reduced in recent years. They perceived that the environmental conditions of the watershed had improved substantially due to these developments being implemented through the Project. The off-site (downstream) effects of Project activities could favorably contribute in reducing environmental damage along the Yangtze River, as soil erosion not only affects the local area, but also vast areas downstream [72].

The leader of Kelang village said that the Project had changed farmers' perception about natural resource management and utilization. Farmers now had greater understanding of the benefits of conserving natural resources, which reduced over-reliance and over-use of forest resources. For example, deforestation had decreased in recent years and farmers were now starting to plant trees in croplands. They were trying to avoid using the practices that lead to increased soil and water losses. In a similar notion, extension agents in Kedu Township also mentioned changes in local perceptions about environmental conditions in Wang Jia after Project implementation. In particular, the reduction in flood incidences was having significant impacts on the village. 


\subsection{Impact on Human Resource Development}

Fifty-four students (47 Chinese and 7 European) received postgraduate (Five Ph.D. and 11 M.Sc.) research opportunities from the SHASEA Project. Four Chinese researchers received an overseas academic degree, of which three were female. This helped train Chinese researchers in European academic institutions. An additional 12 Chinese students conducted experiments in the SHASEA Project for their undergraduate degree. Similarly, the SHASEA Project produced many publications; most of them, however, are not in the public domain [20].

\subsection{Impact on Women}

The Project did not have any gender-differentiated activities. Any participation of female farmers in Project activities was incidental. There appeared to be higher aspiration among male members in Kelang village to be involved in off-farm activities. This was apparent, as $63 \%$ of women in the village worked full-time on the farm, compared with only $22 \%$ of men [20]. This had increased the role of women in farming activities. In this situation, any contribution of Project activities in increasing household income and reducing drudgery would help women more than men. Projects implemented with participatory approaches tend to improve female participation in Project decision-making processes [67]. This can lead to positive changes in the way women are viewed by society.

\section{Project Strengths}

\subsection{Working to the Local Government Agenda}

One positive aspect of the SHASEA Project was that it attempted to address a priority issue of the local Government by embedding the regional priority of improving corn-based cropping systems into its main research and development agenda. International development schemes have been criticized for imposing their own research/development agendas on host countries/organizations rather than solving the problem(s) identified by the host countries/organizations themselves. Funding and technical assistance agencies tend to adhere to their own interests, priorities and procedures [73].

\subsection{Working with Existing Local Research and Development Networks}

The research team comprised a balanced mixture of subject matter specialists from European partner institutions and development experts from local Government institutions of the host countries (China and Thailand). The involvement of local extension agents and political leaders in the research team facilitated the integration of Project outputs into the existing Government structure for information dissemination. Effectiveness of the dissemination can be increased when it is achieved through existing structures $[50,62]$. 


\section{Project Weaknesses}

\subsection{Lack of Participatory Approach}

The participation of local stakeholders in most Project processes and activities was limited to researchers, extension agents and political leaders. Farmers were not actively involved in planning and decision-making processes. Generally, farmers were informed later about decisions on Project activities. This did not create problems in implementing the Project; however, lack of orientation of farmers in participatory approaches and actions resulted in poor communication and understanding between farmers and Project personnel. For example:

a. Farmers' hidden agenda about irrigation: The irrigation system was not originally planned by the researchers. This activity was added later upon demands from local stakeholders. Group discussion revealed that farmers were happy to have the irrigation system in place, but the use of irrigation was very limited during the entire Project. Subsequent discussion with Key Informants revealed that farmers wanted the system for more profitable crops (tobacco or vegetables), which require irrigation. Better communication and understanding between farmers and researchers would have been established if farmers' participation had been sought earlier in Project processes and activities.

b. Chinese tradition and farmers' response attitude: Farmers were very hesitant to mention project weaknesses and limitations. Despite requests to identify Project weaknesses (which would provide a basis for future improvement), farmers avoided negative responses, particularly when the matter was discussed in groups (possibly in front of outsiders/foreigners). During group discussions, farmers mentioned only those points they thought researchers would like to hear. For example, farmers said 'the quality of crops has increased because of irrigation' although the use of irrigation was very limited. Moreover, the degree of adoption of Project technologies estimated during group discussion was generally greater than estimates made during personal interviews in the household survey. Hence, farmers' responses during the PRA exercise were more positive than in the household survey and individual discussions. At least some weaknesses of Project's activities were mentioned in the household survey. This could be due to lack of experience of farmers in participatory approaches. Song [74] reported that a participatory approach was introduced in rural development projects during the early 1990s in China. However, the concept of participatory action was new to farmers and village officials in Kelang village. Farmers were au fait with the 'top-down' approach of the Government. Thus, triangulation (use of information from different sources to draw conclusions) became necessary for information collected in group exercises like PRA. Farmers usually gave credit for production increases to better seed quality, whatever the real reason for increased crop production. This was the traditional way of thinking for the farmers, even though they realized other factors were also responsible for increased productivity.

c. Discrepancy between response, commitment and action: Discrepancies in farmers' responses (in terms of their willingness to adopt or their estimation of future adoption) and actual actions were sometimes observed. For example, farmers highlighted the benefit of irrigation, but few used it. Similarly, farmers praised the Project for protecting the watershed and implementing 
conservation activities that improved environmental conditions. They also said the Project approach and farmers' approach to soil and water conservation were similar, but they were quarrying two hilltops in the watershed for rock extraction. This increased the risk of soil erosion and landslides on such steep slopes.

\subsection{Appropriateness of Subsidy: Subsidy, Orientation and Farmers' Attitude}

Subsidy, in the form of free inputs and labor compensation, was provided to farmers to promote implementation of Project technologies, but due to the lack of a participatory approach, there was insufficient understanding about these subsidies. The objectives of the subsidy and duration of subsidy were not sufficiently discussed with farmers, which increased farmers' expectations for subsidy from the Project. Moreover, farmers' over-estimated their inputs [75]. The input data provided by farmers was much greater than data from plot experiments (actual data) [44]. Farmers might have deliberately over-estimated inputs, expecting to receive more subsidies. Project researchers also perceived that this was one of the reasons for over-estimation of input costs by farmers.

\subsection{Unrealistic Ambition}

Improving cropping systems and environmental conditions at watershed level are potentially longer-term activities. Similarly, it requires longer project duration to realize the benefits from some technologies at household level, such as tree planting. Despite having such longer-term objectives, the Project was planned for a short duration (three years), following EU guidelines. Considering the tendency of slow changes in agricultural systems, Hudson [76] suggested a 10-year horizon for soil conservation projects as a norm. This was a weak aspect of the Project.

The trees in the watershed were still young and vulnerable to damage from livestock at Project completion. They needed to be protected for some time until acquiring greater height and girth. Rehabilitation of gullies was in progress, which could suffer setbacks if watershed protection was discontinued. Farmers had experienced a reduction in flood incidences, but had not been able to see changes in vegetation cover and their effect on soil-water losses and local hydrology. Farmers would be convinced about the benefit of Project activities and soil-water conservation only if they had the opportunity to see them in the field. This could be instrumental in persuading farmers and extension agents to extrapolate practices elsewhere. Moreover, the main phase of the Project had invested in the evaluation of technologies in the watershed and was already completed by December 2002. Wider dissemination of Project technologies and farmer training had been planned for a second phase; however, the Project team's application to the EU for an extension of the project was unsuccessful. Thus, the Project came to an end, having completed planned short-term activities, but without achieving longer-term objectives. This has two implications:

a. The delivery of benefits of the international development program to target group(s) remained incomplete, which reduced the effectiveness of the program.

b. Farmers experienced the outcomes of the first international development assistance to be implemented in the area. If the environmental condition of the watershed returned to its preProject condition and if farmers did not realize any benefits from Project technologies, then they might develop negative perceptions of international development programs. If this 
happened, it might be difficult to gain their participation and co-operation in future development projects.

A longer-term commitment was essential to achieve Project objectives. Adequate and continuous funding has been identified as one of the important factors responsible for project success [39]. However, the restrictions imposed by the EU Framework Program meant that the Project was of short duration. It was assumed that the host institutions would continue Project work after the first phase of the international co-operation funded by the EU. This was the rationale for funding long-term Projects for a short duration. At the local level, however, there were no effective plans to continue the Project work, as assumed by the funding agency. Instead there was an expectation for further funding for the Project from the funding agency. Thus, it may be an appropriate time to review whether such assumptions work in real-life situations and what may be needed to improve the effectiveness of such international co-operation. These are some of the issues which funding agencies, such as the EU, should consider to enhance international co-operation.

\section{Issues Related to Adoption of Project Technologies}

\subsection{Size of Land Holding versus Adoption of Improved Technologies}

Farmers in Wang Jia were reluctant to invest extra resources (labor and money) to reduce soil and water losses, improve soil fertility and maintain crop productivity if total household income was not increased. Most farmers have small and fragmented landholdings [77,78 as cited by 79], thus only a small proportion of their total household income comes from the watershed. Therefore, they are less interested in carrying out extra work to achieve a relatively small increase in their total income or to improve soil conservation. Under these circumstances, if they continue with their traditional cultivation practices, land quality will progressively deteriorate with time and hence crop productivity will decline along with financial returns. However, farmers neither agreed to give up cultivating their land nor improve its condition. This indicates that simply demonstrating technologies that improve productivity or soil conservation may be insufficient. More proactive measures may be required to achieve more extensive adoption. A suitable solution to this situation is perhaps beyond the reach of a Project such as SHASEA; such solutions must be addressed by national policies.

In China, land fragmentation occurred as a result of production system reforms from collective to household production systems during the late 1970s [80]. Subsequently, agricultural production increased substantially during the initial years of reform, peaking in 1984, but this success was not sustained for longer periods [81]. Small-scale production was one of the reasons for the low economic profit of crop farming; thus the sustainability of crop production was negatively affected [82 as cited by 81$]$.

\subsection{Land Security versus Farmers' Stewardship towards Land Resources}

Land rights in China are still incomplete as the trading of rural land is forbidden and farmers only have user rights [79]. Farmers still lack a sense of land security. Over $40 \%$ of farmers in Kelang village thought that the Government would take back their land. Similarly, $>25 \%$ of households were unaware of the allocation of land to farmers for 30 years [30]. Effective stewardship of land resources 
will be difficult to achieve in practice while insecurity and ignorance about land tenure exist among farming communities. For example, farmers in Vietnam changed their farming practice to perennial crops in response to the introduction of long-term land security [83].

\subsection{Awareness versus Adoption}

Initial adoption/adaptation of Project technologies was influenced by farmers' awareness of the technology. Farmers were more aware of polythene mulch, contour cultivation, intercropping and tree planting technologies than others [84]. This led to a comparatively high initial uptake of polythene mulch, contour cultivation, sweet chestnut and intercropping technologies. Farmers had inadequate knowledge about some Project technologies, the adoption of which was particularly low. This reveals the need for increasing farmers' awareness about the rationale for project technologies to achieve greater adoption/adaptation of project technologies by farmers over wider areas. In addition, the willingness to adopt the technology was more among farmers who tested/tried the technology than those who were just aware. There was a significant positive association between the number of farmers who were aware of the technologies and the number of farmers willing to adopt them $(r=0.788$, $\mathrm{P}<0.05, \mathrm{n}=8$ ). When farmers' awareness was high, there was a very high willingness to embrace the technologies (Figure 3). There was a similar, but stronger, association between the number of farmers' who tried/tested the technology and their willingness to adopt the technology $(\mathrm{r}=0.994, \mathrm{P}<0.001$, $\mathrm{n}=8$ ). This implies that both awareness among farmers about the technology and their testing contributes positively to adoption/adaptation. Comparatively farmers' testing of the technology leads to better adoption/adaptation compared to mere awareness. However, considerable time and resources are required for testing/trying the technology, which justifies the usefulness of comparatively rapid and less resource demanding options for awareness creation. Development of effective cropping technologies is important for sustainable agricultural development. The success of any agricultural development project, especially in terms of improving sustainability, depends on how widely those improved technologies are adopted/adapted by farmers in the targeted region. Therefore, farmers' adoption of technologies should be a key criterion for judging project success. The awareness-adoption matrix is a useful tool to guide research and development projects to achieve expected adoption/adaptation of technologies [84]. Use of the matrix helps identification of weak and strong aspects of research and development projects and thus assists strategic decision-making (Figure 3).

Figure 3. Conceptual diagram to illustrate farmers' awareness and adoption of Project technologies/development interventions in Kelang village, 2002 (based on discussions with farmers and key informants and personal observations).

Four conditions of technological awareness and adoption:

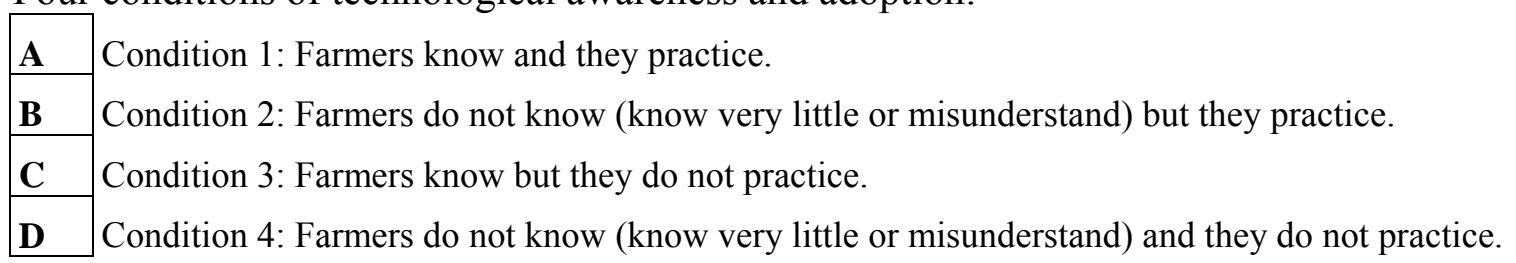


Figure 3. Cont.

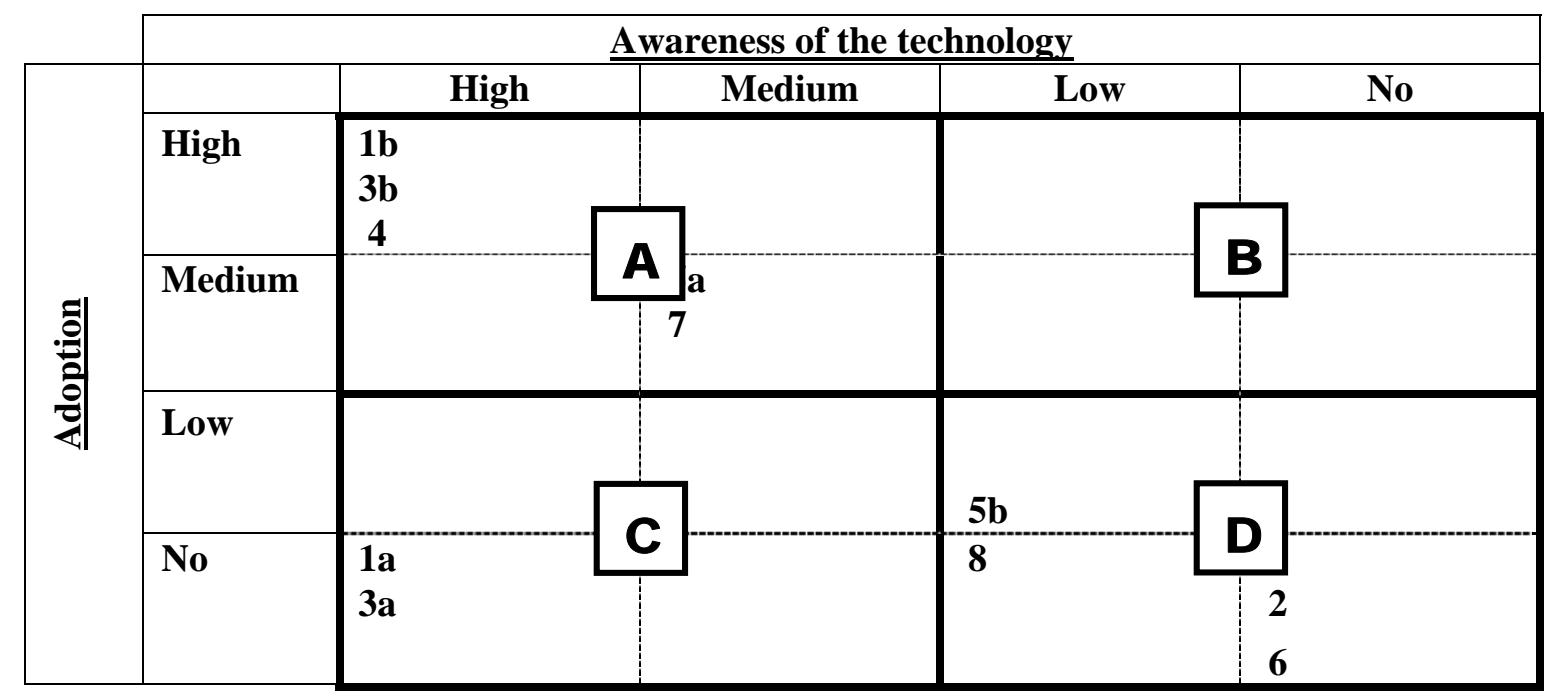

Note:

Symbol Technologies

1a Polythene mulching for corn.

1b Polythene mulching for tobacco.

2 Straw mulching.

3a Use of irrigation for corn.

$3 b \quad$ Use of irrigation for tobacco.

4 Contour cultivation.

5a Intercropping (farmers' existing practice).

$5 \mathrm{~b} \quad$ Intercropping (recommended improved practice).

$6 \quad$ Use of grass strips.

$7 \quad$ Sweet chestnut planting.

$8 \quad$ Prickly ash planting.

(Source: Subedi et al. [84]).

Muhammad et al. [85] studied the awareness of improved sugarcane technologies and adoption by farmers in Pakistan. There was very poor adoption of improved sugarcane technologies where farmers' awareness of the technology was low. Kassioumis et al. [86] also found lack of knowledge to be an important reason for not adopting tree planting in Greece. Poor access to improved knowledge was one of the important factors contributing to land degradation in Nepal [52]. Similarly, education and training greatly increased the likelihood of adoption of soil and water conservation practices by farmers in Burkina Faso [87]. The adoption process comprises five stages: awareness, interest, evaluation, trial and adoption [88 as cited by 89]. Farming households go through these five stages before making any decision about the adoption of new farming technologies. This is a decision-making process and the adoption of new technology can be discontinued at any time, based on the farmers' decision at any of these five stages [89]. This theory identifies that farmers' awareness is the first key stage to adoption of new technology by farmers.

There is a tendency of projects to skip the first two stages of the adoption process and this results in needing to persuade farmers at the evaluation stage. This can result in high initial adoption followed 
by widespread rejection. For example, more than two-thirds of participating farmers discontinued soil and water conservation technologies extended by the Thai-German Highland Development Program (TG-HDP), when farmers found that the technologies did not work as explained by the Project team [89]. Farmers were unaware that soil and water conservation technologies take time to produce beneficial effects, so they could not exhibit improvement compared with farmers' traditional practice within a short timeframe.

Cruz [90] reported the importance of awareness in the adoption of soil conservation measures in the upper watershed of the Phulangi River Basin in The Philippines. Farmers' enthusiasm about the importance of hedgerow systems in controlling soil erosion, improving soil fertility and increasing crop production was increased due to increased awareness resulting from a project education program.

\subsection{Project Duration versus Adoption of Project Interventions}

Desk review revealed a trend of decreasing project duration over time [91]. The duration of the later implemented projects was shorter compared to projects initiated earlier $\left(\mathrm{r}=-0.593^{* * *}, \mathrm{n}=719\right)$. In addition, the duration of $585(81 \%)$ studied projects was $\leq 6$ years. Longer duration projects were successful in addressing more holistic issues than short projects. But, funding agencies are tending to fund shorter-duration projects, so projects are progressively becoming shorter. However, the number of projects implemented each year is increasing over time. Despite the decrease in total development assistance, increased project numbers, particularly after 1986, appears to be at the expense of project duration. Short project duration was one of the most cited reasons for not completing some essential dissemination activities to lead to wider adoption. It is difficult to produce tangible outputs from agricultural and soil conservation projects within five years. Considering the slow changes in the system, agro-environmental sustainability projects are advised to plan for a minimum of 5-10 years, depending on the nature of activities. We propose it is time for funding agencies to reconsider their tendency to fund shorter duration projects.

\section{Effectiveness in Relation to Other Development Projects}

In this section the SHASEA Project is compared with similar projects implemented in South-East Asia. The objectives, activities, duration and achievements of different projects were studied. The comparison is based on available information about the other projects, which was collected from various sources.

\subsection{Achievement of Project Objectives}

The SHASEA Project was successful in completing the planned activities and achieved its scientific objectives. Despite this success, early indications are that the adoption of Project technologies by farmers both inside and outside the watershed will be low. This is a typical situation with soil conservation projects, as other studies reported low adoption of soil conservation technologies by farmers $[38,40,92,93]$. The real impact of the success in plot studies at watershed level is possible only after the wider adoption of Project technologies by farmers. 
There are some initial signs of improvement in environmental conditions within Wang Jia Watershed, but it is too early to claim any lasting improvement, because changes in the system occur slowly [76]. Moreover, the positive effects of Project technologies on environmental conditions can only be expected if the watershed is protected from unrestricted grazing, further deforestation on upper slopes and increased cultivation on steep slopes.

The Chinese-Swedish Soil Conservation Project was similar to the SHASEA Project in many aspects. Both projects aimed at improving crop production and reducing soil erosion [94]. Both projects were ambitious in setting their objectives as they attempted to study and address the complex issues of cropping systems within a short time-frame (3 years). Hudson [76] reported that over-optimism regarding soil conservation projects implemented in Africa was one of the main factors for design-faults leading to project failure. Longer duration projects, such as the Thai-German Highland Development Program (TG-HDP) (1981-1998) and the Thai-Australian Highland Agricultural and Social Development (TA-HASD) Project (1982-1993) were successful in addressing more holistic issues than short duration projects like the SHASEA and Chinese-Swedish Soil Conservation Projects [95,96].

\subsection{Effectiveness of Technology Developed}

The final report of the SHASEA Project indicated that the scientific outcomes of the Project were very successful [20] and farmers in Wang Jia endorsed this claim. However, the farmers' reluctance to use straw mulch, the recommended intercropping practices and irrigation raised questions regarding the appropriateness of these technologies in existing farming systems and doubts regarding future adoption/adaptation of these technologies by farmers. The longer-term effects of Project technologies and development intervention; for example, the effects of contour cultivation on soil fertility and soil-water losses and the impact of tree planting on the environmental conditions in the watershed, have yet to be realized and the outcomes remain inconclusive. This is a classic problem of a shortduration project, which generally achieves considerable success in producing output from activities that can be accomplished quickly, but fails to draw meaningful conclusions from activities that require a longer period to mature. For example, the Thai-German Highland Development Program (TG-HDP, a longer duration project) was successful in improving living standards of the people [96-98]. Similarly, another longer-duration project, the Thai-Australian Highland Agricultural and Social Development Project (TA-HASD) achieved all agricultural, environmental and social output targets [95], but short duration projects like the Chinese-Swedish Soil Conservation Project and SHASEA could not conclude on outcomes from agro-forestry experiments and environmental objectives were incomplete [20,99]. Dirksen [97] identified long-term commitment as one of the most important factors for the success of TG-HDP.

Short-duration projects often fail to measure the extent of adoption/adaptation of project activities and impact of project activities on existing farming systems, because of their short stay in the target area. Often evaluation conducted during or immediately after project completion [for example 99-101] does not give the fullest picture, because of slow realization about the benefit of the technology by farmers, leading to slow uptake. This makes it difficult to determine project impact, unless evaluation of project activities can be extended beyond the project [102]. So, it is important to study the extent of 
adoption/adaptation of project activities and the impact of project activities some time after project completion, in order to decide if it is worth extrapolating these outcomes to similar areas.

\subsection{Dissemination and Scaling Up}

The SHASEA Project carried out all farmer-level dissemination and scaling-up activities within Wang Jia. The Project required its entire duration for the direct evaluation of technologies and establishment of development interventions. There was little time left for wider dissemination, except within the scientific community. However, dissemination within the watershed was planned well in the Project proposal [24] and was achieved. But in order to achieve the full impact of project activities in improving sustainability, technologies need to be adopted across wider areas. Often the outcomes of short-duration projects do not cross the boundaries of experimental stations, identifying on-farm testing and wider dissemination only as areas for future work [94,99].

The SHASEA Project put considerable effort into disseminating Project outcomes to scientific communities. It produced numerous publications, organized the 'Workshop on Sustainable Highland Agriculture in South-East Asia (SASEA)' in Yunnan Province, organized a post-Congress tour (Red Cloud Tour) for the participants of the ' $17^{\text {th }}$ World Congress of Soil Science' in Bangkok (14-21 August 2002) and created a website about Project activities [20]. In recent years, many projects have emphasized the documentation of their activities and most produce impressive portfolios of documents [for example 94,96,103]. The funding agencies' requirement for various reports could be one of the driving forces for the production of these documents, but few of these are published and readily accessible in the public domain (e.g. refereed journals). With the development of the internet, many projects/organizations now place their publications on websites, which makes information more accessible.

\section{Overall Success and Failure}

There is a general tendency to consider the completion of project activities as the full achievement of project objectives, demonstrating project 'success.' Completion of activities is certainly an achievement of an immediate objective, however, this should not be considered as the ultimate project success if it fails to make sufficient, lasting improvements for target beneficiaries [104]. Various authors and organizations have used different definitions of project success. Based on an evaluation of 40 soil conservation projects in Africa, Hudson [76] defined success as the extent to which a project achieved its objectives. However, when sustainable improvement of farming systems is considered, merely the accomplishment of project activities may be insufficient for a project to be judged successful. The technical superiority of any technology alone cannot make any positive contribution to the system, unless it is widely used by farmers and technical superiority is not the only factor that farmers consider for adoption.

Edwards and Farrington [59] considered level of uptake of project outputs by users to be the main criterion for judging project success. However, they realized that level of uptake depends on the way projects are managed throughout the project cycle. So they considered different stages of the project cycle, including relevant issues beyond the main project cycle, to determine project success. 
The criteria for judging overall project success and failure can be different and debatable. In addition, projects implemented to improve agricultural sustainability are generally holistic, multidisciplinary and multi-faceted, which pose greater complexity in evaluating their overall success. Moreover, 'success for whom?' is an important question where different actors will probably have different perspectives of success, for example farmers are likely to choose the indicators of immediate success at household level, while donors may expect impacts over longer periods and may be more concerned on impacts over a larger domain [92]. These authors have suggested a wide range of criteria (for example, level of uptake, farmers' involvement in all stages of the project, post-project continuation of uptake, effect on income and food security, downstream effects, effect on land security and other policy adjustments) as possible measures of success.

Often the achievements of different activities of the project are discussed separately, rather than rating their overall success [for example 99]. Short duration projects usually report achievements in small activities that can be completed relatively quickly, for example, establishing infrastructures, completing field crop research, providing training, or publishing reports [20,94].

Superficial and more detailed studies have both advantages and limitations. Superficial studies provide inadequate details about project effectiveness, while more detailed studies are expensive and require more time and human resources. A more practical method to evaluate project success would be to measure the current uptake and study the perceptions of users for the future use of project technologies. In addition, institutionalization of research outputs by extension services for wider dissemination may be an important indicator of project success.

\section{Conclusions}

The conclusions of the evaluation of SHASEA Project are:

- The SHASEA Project was successful in achieving its scientific and technical objectives. Some technologies introduced by the Project were effective in improving crop productivity and reducing soil and water losses. But at the end of the three-year project, it was not clear what the potential long-term benefits would be.

- Other short-duration projects have produced similar outcomes. By contrast, longer duration projects are able to commit more time to dissemination and to follow through to the processes of adoption and adaptation and possibly achieve greater long-term success. Alternatively local systems must be put in place to continue the developments introduced by the project after the main funding period is completed.

- This study investigated the initial uptake of Project technologies by farming communities in Wang Jia Watershed, their perceptions about the usefulness of the technologies and their intentions for future adoption. The study revealed that despite the technical and scientific success of the Project, long-term adoption of many introduced practices will be low, unless considerable incentives are used or much more effective dissemination techniques employed.

- Outcomes would have improved considerably if participatory approaches had been used from the outset, to engage farmers more fully with the project, to ensure that the practices introduced were as appropriate as possible, to achieve greater ownership of objectives and outcomes, leading to higher adoption rates. 
- More emphasis should have been given to the dissemination of the outcomes at farmer level outside the study watershed and there should have been more involvement with regional policy- makers and extension officials throughout the program.

- Longer-term improvements in sustainability at the watershed level have not yet been demonstrated. Continued use of contour cultivation and extension of the tree planting schemes may lead to significant improvements in sustainability in the future.

\section{Good Practices for the Development, Implementation and Dissemination of Similar Projects in the Future}

The following points are presented as recommendations of good practice for planning/designing, implementing and disseminating research and development projects.

- Work in accordance with the research and development agenda of local stakeholders. This will help to ensure that project efforts will be effective in alleviating local problems and achieving local needs.

- Work with existing local research and development networks. This is helpful in integrating project outcomes with existing local research and development systems and is important to ensure wider dissemination of research and post-project utilization of project outputs.

- Ensure adequate sharing of project goals with all partners and stakeholders, so that all partners and stakeholders are aware of the project mission and their roles, responsibilities and contributions necessary to achieve project objectives; local ownership of the project is very important.

- Avoid ambitious planning of project activities that cannot be completed within the stipulated time and resources. If any activities are expected to remain incomplete by the end of the project or as a result of limited availability of resources, then continuation strategies for the completion of such activities should be in place. The continuation strategy may include identification of activities to be completed, institutions to be responsible and sources and amount of resources.

- Record baseline information before the start of project interventions, in order to study project progress and effectiveness in the areas of intervention.

- Use farmer participatory approaches in all stages of research and development, i.e., planning, implementation, evaluation and dissemination (scaling-up). Farmers were capable of evaluating environmental conditions in a watershed, identifying suitable indicators and using them during evaluation. Effective dissemination can be achieved by involving farmers in the scaling-up process, as 'other farmers' were major sources of information for farmers.

- Ideally, consider technology with the following characteristics: appropriate balance between rapid returns and longer-term benefits; inputs associated with locally available technology, in time and at reasonable cost; the technology should not demand extra labor and costs without the extra returns being clearly identified; and new or modified technologies should be capable of being accommodated within the existing system. Where these ideal conditions are not met, it should be recognized that additional incentives may be required to improve adoption.

- Provide adequate training to increase farmers' awareness about the longer-term benefits of conservation strategies and thereby achieve more effective dissemination and adoption. 
- Provide subsidy or compensation to farmers where additional income from the technology is delayed or remains less than current income for some time. It is necessary to fully discuss the objective and duration of such subsidy or compensation programs with farmers.

- Involve policy-makers at an early stage in the project if policy support is likely to be required to achieve project objectives. This is particularly important when attempting to improve sustainability, which may not be associated with tangible short-term benefits.

- Discuss and agree future (post-project) courses of action with local partners. Ensure that the funding agency's conditions are fully understood and accepted by all partners. Where possible, sources of on-going local support should be identified while the main project is operational.

\section{Suggested Areas for Future Study}

The following points are presented below as suggestions for further investigation.

- Generation of post-project baseline information would help in monitoring progress in the adoption and impact of project technologies for the future.

- Under researcher-managed plots, the integrated INCOPLAST technology proved successful in both increasing crop productivity and improving soil and water conservation. However, very few farmers adopted the whole package of this technology, while most farmers adopted some components of the system. It is necessary to further investigate the factors, both technical and socio-economic, which limited the adoption of this effective integrated cropping system.

- Low availability was one of the major reasons for poor initial uptake of straw mulch technology. Investigation of ways to increase straw production is necessary to achieve better adoption of this technology by farmers.

- This study presents information about the monitoring of impacts and the early adoption of Project technologies by farmers. Wider adoption of technologies at the time of this study was limited and a much longer monitoring period would be required to draw definitive conclusions on long-term adoption and the wider socio-economic impacts of the development program.

- Farmers were reluctant to use the intercropping system recommended by the Project. Lack of suitable varieties, particularly of the companion crop, was an important reason. Further work is required to develop more appropriate systems for this area.

- Effects of 'white pollution' (pollution due to polythene) on the cropping environment should be studied and ways for reducing any adverse effects investigated.

- Government subsidy on polythene is probably one of the reasons for its widespread use for mulching; however, this subsidy may not continue indefinitely. Further studies should investigate how farmers will respond if the subsidy on polythene is lifted by the Government.

- Farmers perceived that use of contour cultivation on sloping lands increased lodging and weed problems, although published information was unavailable to verify these perceptions. A further study should investigate the relationships between contour cultivation, weed problems and tendency to lodge. 


\section{Acknowledgements}

M. Subedi thanks the University of Wolverhampton for providing a research studentship to conduct this work. Thanks are due to An TongXin, Li YongMei, Liu HongMei, students of Yunnan Agricultural University and farmers of Kelang village who helped in the field studies.

\section{References}

1. Brady, N.C. Making agriculture a sustainable industry. In Sustainable Agricultural Systems; Edwards, C.A., Lal, R., Madden, P., Miller, R.H., House, G., Eds.; Soil and Water Conservation Society: Ankeny, IA, USA, 1990.

2. Pretty, J.N. Regenerating Agriculture: Policies and Practice for Sustainability and Self-Reliance; Vikas Publishing House Pvt.: New Delhi, India, 1995.

3. Harwood, R.R. A history of sustainable agriculture. In Sustainable Agricultural Systems; Edwards, C.A., Lal, R., Madden, P., Miller, R.H., House, G., Eds.; Soil and Water Conservation Society: Ankeny, IA, USA, 1990.

4. Jackson, W. New Roots for Agriculture; Friends of the Earth: San Francisco, CA, USA, 1980.

5. Rodale, R. Breaking new ground: The search for a sustainable agriculture. Futurist 1983, 1, $15-20$.

6. Shepherd, A. Sustainable Rural Development; MacMillan Press: London, UK, 1998.

7. Hurni, H. Soil conservation policies and sustainable land management: A global overview. In Soil and Water Conservation Policies and Programs: Successes and Failures; Napier, T.L.; Napier, S.M.; Tvrdon, J., Eds.; CRC Press: Boca Raton, FL, USA, 2000.

8. Rasul, G.; Thapa, G.B. Sustainability of ecological and conventional agricultural systems in Bangladesh: an assessment based on environmental, economic and social perspectives. Agric. Syst. 2004, 79, 327-351.

9. Rigby, D.; Woodhouse, P.; Young, T.; Burton, M. Constructing a farm level indicator of sustainable agricultural practice. Ecol. Econ. 2001, 39, 463-478.

10. Röling, N. Gateway to the global garden: Beta/gamma science for dealing with ecological rationality. In The Earthscan Reader in Sustainable Agriculture; Pretty, J., Ed.; Earthscan: London, UK, 2005.

11. Barton, A.P.; Fullen, M.A.; Mitchell, D.J.; Hocking, T.J.; Liu, L.; Wu, B.Z.; Zheng, Y.; Xia, Z.Y. Effects of soil conservation measures on erosion rates and crop productivity on subtropical Ultisols in Yunnan Province, China. Agric. Ecosyst. Environ. 2004, 104, 343-357.

12. Fullen, M.A., Milne, E., Huang B.Z., Eds. The Red Cloud Tour: Guidebook to the 'Red Cloud Tour' of Yunnan Province, China. August 22-28, 2002; Sustainable Highland Agriculture in South-East Asia (SHASEA) Research Group: Wolverhampton, UK, 2002.

13. Lu, C.H. A scenario exploration of strategic land use options for the Loess Plateau in Northern China. Agric. Syst. 2004, 79, 145-170.

14. Rerkasem, K. An assessment of sustainable highland agricultural systems in Thailand. Thailand Develop. Res. Instit. (TDRI) Quart. Rev. 1995, 10, 18-25. 
15. Treitz, W.N. Dimensions and importance of sustainability in a global context. In Evaluation for Sustainable Land Management in the Developing World: Technical Papers, IBSRAM Proceedings No. 12(2); Dumanski, J., Pushparajah, E., Latham, M., Myers, R., Elliott, C.R., Eds.; The International Board for Soil Research and Management (IBSRAM): Bangkok, Thailand, 1991.

16. Cai, Y.L.; Zhang, J.L.; Zhu, X. Land Policies, Land Management and Land Degradation in the Hindu Kush-Himalayas-China Study Report; International Centre for Integrated Mountain Development (ICIMOD): Kathmandu, Nepal, 2000.

17. Huang B.Z. Effects of cultivation techniques on maize productivity and soil properties on hillslopes in Yunnan Province, China. Ph.D. Thesis; The University of Wolverhampton, UK, 2001.

18. Gao, Z.; Zhou, L. The aggravation of soil erosion in the south-western Region. Sci. Technol. 1988, January.

19. Shi, D.M. Degradation and conservation of red soils in China. Soil Water Conserv. China 1987, 12, 2-5.

20. SHASEA. Improving the productivity and sustainability of crop systems on fragile slopes in the highlands of South China and Thailand. Final Report. Sustainable Highland Agriculture in South-East Asia (SHASEA) Research Group. The University of Wolverhampton, UK, 2003.

21. Cornwall, A.; Guijt, I.; Welbourn, A. Acknowledging the process: Methodological challenges for agricultural research and extension. In Beyond Farmer First: Rural People's Knowledge, Agricultural Research and Extension Practice; Scoones, I., Thompson, J., Eds.; Intermediate Technology Publications: London, UK, 1994.

22. Kelang Village Authority. Village Record. 2002.

23. Fullen, M.A.; Hocking, T.J.; Mitchell, D.J.; Milne, E.; Wilson, M.J.; Cuddy, M.; Steele, S.; McDonough, T.; Bock, L.; Dautrebande, S.; Lacroix, D.; Casse, C.; Vinck, P.; Baudoin, J.G.; Van Caillie, D.; Wu, B.Z.; Liu, L.G.; Li, Y.M.; Huang, B.Z.; Sun, H.Q.; Chen, J.D.; Wang, S.H.; Liu, H.M.; Wang, Y.Z.; Ma, C.Y.; Pu, J.L.; Jin, Z.B.; Ma, S.Y.; Panomataranchagul, M.; Sukkasem, C.; Peukari, S. Multidisciplinary approaches to soil conservation in the highlands of South China and Thailand. In Multidisciplinary Approaches to Soil Conservation Strategies; Helming, K., Ed.; ZALF (Zentrum für Agrarlanschafts- und landnutzungsforschung e.V.): Müncheburg, Germany, 2001; pp. 139-145.

24. SHASEA. Improving the productivity and sustainability of crop systems on fragile slopes in the highlands of South China and Thailand. Project proposal to the European Union. The University of Wolverhampton, UK, 1997.

25. Fukuda-Parr, S.; Lopes, C.; Malik, K. Overview. In Capacity for Development: New Solutions to Old Problems; Malik, K., Ed.; Earthscan: London, UK, 2002.

26. Uphoff, N. The agricultural development challenges we face. In Agroecological Innovation: Increasing Food Production with Participatory Development; Uphoff, N., Ed.; Earthscan: London, UK, 2002.

27. Garforth, C.; Rehman, T.; McKemey, K.; Tranter, R.; Cooke, R.; Yates, C.; Park, J.; Dorward, P. Improving the design of knowledge transfer strategies by understanding farmer attitudes and behaviour. J. Farm Manag. 2004, 12, 17-32. 
28. Rondinelli, D.A. Development Projects as Policy Experiments: An Adaptive Approach to Development Administration, 2nd ed.; Routledge: London, UK, 1993.

29. Subedi, M.; Hocking, T.J.; Fullen, M.A.; McCrea, A.R.; Milne, E.; Wu, B.Z.; Mitchell, D.J. An evaluation of the introduction of modified cropping practices in Yunnan Province, China, using surveys of farmers' households. Agric. Sci. China 2009, 8, 188-202.

30. Subedi, M. Effectiveness of an agricultural technology research and development project for increasing sustainability of cropping systems in upland areas of Yunnan Province, China. Ph.D. Thesis; The University of Wolverhampton, UK, 2006.

31. Bhatia, K.S.; Choudhary, H.P. Runoff and erosion losses and crop yields from slopy and eroded alluvial soils of Uttar Pradesh in relation to contour farming and fertilization. Soil Conserv. Digest 1977, 5, 16-22.

32. Liu, G.C.; Gao, M.R.; Zhu, B. The characteristics of overland flow under varied tillage and cropping systems in Sichuan Basin, China. Soil Till. Res. 2000, 54, 139-143.

33. Milne, E. Soil conservation in relation to maize productivity on sub-tropical red soils in Yunnan Province, China. Ph.D. Thesis; The University of Wolverhampton, UK, 2001.

34. Neal, M.E.B. Soil erosion by water, some measures for its control on agricultural lands. In Proceedings of the Open Meeting of the Agricultural Engineering Branch of the Food and Agriculture Organization (FAO), Rome, Italy, 1963.

35. Poudel, D.D.; Midmore, D.J.; West, L.T. Farmer participatory research to minimize soil erosion on steepland vegetable systems in The Philippines. Agric. Ecosyst. Environ. 2000, 79, 113-127.

36. Shi, Z.H.; Cai, C.F.; Ding, S.W.; Wang, T.W.; Chow, T.L. Soil conservation planning at the small watershed level using RUSLE with GIS: a case study in the Three Gorge Area of China. Catena 2004, 55, 33-48.

37. van Keer, K., Comtois, J.D., Turkelboom, F., Ongprasert, S., Eds. Options for Soil and Farmer Friendly Agriculture in the Highlands of Northern Thailand; Deutsche Gesellschaft für Technische Zusammenarbeit (GTZ) GmbH: Eschborn, Germany, 1998.

38. Fujisaka, S. Thirteen reasons why farmers do not adopt innovation intended to improve the sustainability of upland agriculture. In Evaluation for Sustainable Land Management in the Developing World: Technical Papers, IBSRAM Proceedings No. 12(2); Dumanski, J., Pushparajah, E., Latham, M., Myers, R., Elliott, C.R., Eds.; The International Board for Soil Research and Management (IBSRAM): Bangkok, Thailand. 1991.

39. Ruaysoongnern, S. Adoption of sloping land conservation practices by farmers in the northeast of Thailand. In Issues and Options in the Design of Soil and Water Conservation Projects; McDonald, M., Brown, K., Eds.; School of Agriculture and Forest Sciences Publication Number 17, University of Wales: Bangor, UK, 1999.

40. Tang, Y. Factors influencing farmers' adoption of soil conservation programmes in Hindu Kush Himalayan region. In Issues and Options in the Design of Soil and Water Conservation Projects; McDonald, M., Brown, K., Eds.; School of Agriculture and Forest Sciences Publication Number 17, University of Wales, Bangor, UK, 1999.

41. SHASEA. Improving the Productivity and Sustainability of Crop Systems on Fragile Slopes in the Highlands of South China and Thailand, First Annual Report; Sustainable Highland 
Agriculture in South-East Asia (SHASEA) Research Group, University of Wolverhampton, UK, 2000.

42. Li, Y.M. A generic protocol for an integrated land information system in humid subtropical highlands: A case study in Yunnan Province, China. Ph.D. Thesis. University of Wolverhampton, UK, 2004.

43. Zhang, Y.T.; Yang, J.H.; Gao, W. A study on effects of different water retention treatments. Bull. Soil Water Conserv. 2000, 20, 46-48 (In Chinese, English abstract).

44. Wang, S.H. Cultivation practices, maize and soybean productivity and soil properties on fragile slopes in Yunnan Province, China. Ph.D. Thesis; University of Wolverhampton, UK, 2003.

45. Barton, A.P. Soil erosion and conservation on arable sub-tropical Ultisols in Yunnan Province, China. Ph.D. Thesis; The University of Wolverhampton: Wolverhampton, UK, 2000.

46. Aina, P.O. Effects of time and duration of mulching on corn (Zea mays L.) in Western Nigeria. Field Crop. Res. 1981, 4, 25-32.

47. Gajri, P.R.; Arora, V.K.; Chaodhary, M.R. Corn growth responses to deep tillage, straw mulching, and farmyard manure in coarse textured soils of N.W. India. Soil Use Manage. 1994, 10, 15-20.

48. Lal, R. Soil temperature, soil moisture and corn yield from mulched and unmulched tropical soils. Plant Soil 1974, 40, 129-143.

49. Wu, X.M. The study of mulch on soil water and crop growth. Arid Agr. Res. 1990, 4, 92-97.

50. Garforth, C. Dissemination Pathways of RNR Research, Socio-economic Methodologies, Best Practice Guidelines; Natural Resources Institute: Chatham, UK, 1998.

51. Brown, L.A. Innovation Diffusion: Retrospect and Prospect. Geography 1990, 42, 153-164.

52. Neupane, H.; Ojha, H.; Garforth, C. Scaling Up of Sustainable Soil Management Practices: Case Studies of Panchkhal and Sanga Villages in Kavre District, Nepal; ForestAction: Kathmandu, Nepal and The University of Reading: UK, 2002.

53. Garforth, C.; Usher, R. Promotion and uptake pathways for research output: a review of analytical frameworks and communication channels. Agric. Syst. 1997, 55, 301-322.

54. Tang, Y.; Zhang, Y.Z.; Xie, J.S.; Sun, H. Incorporation of mulberry in contour hedgerows to increase overall benefits: a case study from Ningnan County, Sichuan Province, China. Agric. Syst. 2003, 76, 775-785.

55. Zhu, X.K. Personal Communication; Yunnan Provincial Bureau of Hydrology and Water Conservancy, Wuhuashan, Kunming, Yunnan Province, PR China, 2003.

56. Garforth, C.J.; Malla, Y.B.; Neopane, R.P.; Pandit, B.H. Socioeconomic factors and agroforestry improvements in the hills of Nepal. Mt. Res. Dev. 1999, 19, 273-278.

57. Wu, B.Z. Personal Communication; Yunnan Agricultural University, Yunnan Province, PR China, 2002.

58. Okigbo, B.N. Sustainable agricultural systems in tropical Africa. In Sustainable Agricultural Systems; Edwards, C.A., Lal, R., Madden, P., Miller, R.H., House, G., Eds.; Soil and Water Conservation Society: Ankeny, IA, USA, 1990.

59. Edwards, D.; Farrington, J. Review of the Factors Influencing the Uptake and Impact of a Sample of Twenty-one Renewable Natural Resources Projects. Network Paper 43; Overseas Development Administration: London, UK, 1993. 
60. Garforth, C.; Angell, B.; Archer, J.; Green, K. Fragmentation or creative diversity? Options in the provision of land management advisory services. Land Use Policy 2003, 20, 323-333.

61. Subedi, A.; Garforth, C. Gender, information and communication networks: Implications for extension. Eur. J. Agr. Educ. Ext. 1996, 3, 63-74.

62. Joshi, K.D.; Gyawali, S.; Witcombe, J.R. Participatory scaling up of participatory varietal selection. In Breeding Rainfed Rice for Drought-Prone Environments: Integrating Conventional and Participatory Plant Breeding in South and Southeast Asia, Proceedings of a DfID Plant Sciences Research Programme/IRRI Conference, IRRI, Los Banos, Laguna, The Philippines, March 12-15, 2002; Witcombe, J.R., Parr, L.B., Atlin, G.N., Eds.; Department for International Development (DfID) Plant Sciences Research Programme (PSP), Centre for Arid Zone Studies (CAZS) and International Rice Research Institute (IRRI): Bangor and Manila, 2002; p.104.

63. Atlin, G.; Witcombe, J.R. Introduction. In Breeding Rainfed Rice for Drought-Prone Environments: Integrating Conventional and Participatory Plant Breeding in South and Southeast Asia, Proceedings of a DfID Plant Sciences Research Programme/IRRI Conference, The Philippines, March 12-15, 2002; Witcombe, J.R., Parr, L.B., Atlin, G.N., Eds.; Department for International Development (DfID) Plant Sciences Research Programme (PSP), Centre for Arid Zone studies (CAZS) and International Rice Research Institute (IRRI): Bangor and Manila, UK and The Philippines, 2002; p. 104.

64. Gupta, A.K.; Patel, K.K.; Vijaya Sherry Chand, P.G.; Pastakia, A.R.; Suthar, J.; Shukla, S.; Koradiya, D.; Chauhan, V.; Raval, A.; Srinivas, C.; Sinha, R. Participatory research: will the Koel hatch the crow's eggs? In New Frontiers in Participatory Research, Proceedings of the International Seminar on Participatory Research and Gender Analysis for Technology Development, Cali, Columbia, 1996; Participatory Research and Gender Analysis Program (PR/GA), International Center for Tropical Agriculture (CIAT): Cali, Columbia, 1996.

65. Paris, T.R.; Singh, R.K.; Atlin, G.N.; Sarkarung, S.; McLaren, G.; Courtois, B.; McAllister, K.; Piggin, C.; Pandey, S.; Singh, A.; Singh, H.N.; Singh, O.N.; Singh, S.; Singh, R.K.; Mandal, N.P.; Prasad, K.; Sahu, R.K.; Sahu, V.N.; Sharma, M.L.; Singh, R.K.P.; Thakur, R.; Singh, N.K.; Chaudhary, D.; Ram, S. Farmer participatory breeding and participatory varietal selection in Eastern India: Lessons learned. In Breeding Rainfed Rice for Drought-Prone Environments: Integrating Conventional and Participatory Plant Breeding in South and Southeast Asia, Proceedings of a DfID Plant Sciences Research Programme/IRRI Conference, IRRI, Los Banos, Laguna, The Philippines, March 12-15, 2002; Witcombe, J.R., Parr, L.B., Atlin, G.N., Eds.; Department for International Development (DfID) Plant Sciences Research Programme (PSP), Centre for Arid Zone Studies (CAZS) and International Rice Research Institute (IRRI): Bangor and Manila, UK and The Philippines, 2002; p. 104.

66. Subedi, M.; Hocking, T.J.; Fullen, M.A.; McCrea, A.R.; Milne, E.; Wu, B.Z.; Mitchell, D.J. Use of farmers' indicators to evaluate the sustainability of modified cropping practices and environmental measures on sloping land: a case study in Yunnan Province, China. Pedosphere 2009, 19, 344-355.

67. Smith, P.D. Participatory soil and water conservation in India-Experiences from the KRIBHCO Indo-British Rainfed Farming Project. In Issues and Options in the Design of Soil and Water 
Conservation Projects; McDonald, M., Brown, K., Eds.; School of Agriculture and Forest Sciences Publication Number 17, University of Wales, Bangor, UK, 1999.

68. Ruaysoongnern, S.; Patanothai, A. Farmers' perception and adoption of sustainable land-management technologies-Thailand's experience. In Evaluation for Sustainable Land Management in the Developing World: Technical Papers, IBSRAM Proceedings No. 12(2); Dumanski, J., Pushparajah, E., Latham, M., Myers, R., Elliott, C.R., Eds.; The International Board for Soil Research and Management (IBSRAM): Bangkok, Thailand, 1991.

69. Li, X.Y.; Zuo, C.S.; Tschirley, J.B.; Webb, S.E.; Morton, A. Sustainable Agriculture and Rural Development in China, Part 1: The Agro-ecosystem and China's Rural Economy. Food and Agriculture Organization (FAO): Rome, Italy, 1997.

70. Huang B.Z. Personal Communication; Yunnan Beef Cattle and Pasture Research Centre, Xiaoshao, Yunnan Province, PR China, 2002.

71. Ravnborg, H.M. Beyond the farm and within the community: Issues of collective action in participatory natural resource management research. In New Frontiers in Participatory Research, Proceedings of the International Seminar on Participatory Research and Gender Analysis for Technology Development, Participatory Research and Gender Analysis Programme (PR/GA), International Center for Tropical Agriculture (CIAT), Cali, Columbia, 1996.

72. D'haeze, D.; Deckers, J.; Raes, D.; Phong, T.A.; Loi, H.V. Environmental and socio-economic impacts of institutional reforms on the agricultural sector of Vietnam: Land suitability assessment for Robusta coffee in the Dak Gan region. Agric. Ecosyst. Environ. 2005, 105, 59-76.

73. Samoff, J. From funding projects to supporting sectors? Observation on the aid relationship in Burkina Faso. Int. J. Educ. Dev. 2004, 24, 397-427.

74. Song, H. Overview of participatory rural development approach: The practice in China. Yunnan Geogr. Environ. Res. 1999, 11, 92-101.

75. Liu, H.M. Personal Communication; Yunnan Agricultural University, Yunnan, China, 2002.

76. Hudson, N.W. A study of the reasons for success or failure of soil conservation projects. In FAO Soils Bulletin 64; Food and Agriculture Organization (FAO) of the United Nations: Rome, Italy, 1991.

77. Chen, H.Q. Land transfer with compensation: experiment and major findings. Chin. Rural Econ. 1992, 37-39.

78. Fleisher, B.; Liu, Y.H. Economies of scale, plot size, human capital and productivity in Chinese agriculture. Q. Rev. Econ. Financ. 1992, 32, 112-123.

79. Guang, H.W.; Enjiang, C. A Micro-empirical analysis of land fragmentation and scale economics in rural China. In China's Agriculture at the Crossroads; Yang, Y.Z., Tian, W.M., Eds.; Macmillan Press Ltd: London, UK, 2000.

80. Ding, C.R. Land policy reform in China: assessment and prospects. Land Use Policy 2003, 20,109-120.

81. Sanders, S. Is ecological agriculture sustainable in China? In China's Economic Growth: The Impact on Regions, Migration and the Environment; Cannon, T., Ed.; Macmillan Press: London, UK, 2000. 
82. Li, W. An analysis on sustainable development of crop production in China. In Paper for the Fourth European Conference on Agriculture and Rural Development of China; Manchester Business School: Manchester, UK, 1995.

83. Phien, T.; Tu Siem, N. Soil conservation extension in agricultural development in Vietnam. In Soil Conservation Extension: From Concepts to Adoption; Sombatpanit, S., Zobisch, M.A., Sanders, D.W., Cook, M.G., Eds.; Science Publishers: Enfield, New Hampshire, USA, 1997.

84. Subedi, M.; Hocking, T.J.; Fullen, M.A.; McCrea, A.R.; Milne, E.; Wu, B.Z.; Mitchell, D.J. An awareness-adoption matrix for strategic decision making in agricultural development projects: A case study in Yunnan Province, China. Agric. Sci. China (In Press).

85. Muhammad, S.; Garforth, C.; Almas, K. Adoption of recommended agricultural technologies by farmers as an indicator of effective communication by extension field staff. Int. J. Agr. Biol. 2001, 3, 13-15.

86. Kassioumis, K.; Papageorgiou, K.; Christodoulou, A.; Blioumis, V.; Stamou, N.; Karameris, A. Rural development by afforestation in predominantly agricultural areas: Issues and challenges from two areas in Greece. Forest Policy Econ. 2004, 6, 483-496.

87. Sidibe, A. Farm-level adoption of soil and water conservation techniques in northern Burkina Faso. Agric. Water Manage. 2005, 71, 211-224.

88. Rogers, E.M. Diffusion of Innovations. The Free Press of Glencoe: New York, NY, USA, 1962.

89. Enters, T. The token line: Adoption and non-adoption of soil conservation practices in the highlands of northern Thailand. In Soil Conservation Extension: from Concepts to Adoption; Sombatpanit, S., Zobisch, M.A., Sanders, D.W., Cook, M.G., Eds.; Science Publishers Inc.: Enfield, New Hampshire, USA, 1997.

90. Cruz, E.B. The adoption of hedgerows as a soil conservation measure in The Philippines. In Soil Conservation Extension: From Concepts to Adoption; Sombatpanit, S., Zobisch, M.A., Sanders, D.W., Cook, M.G., Eds.; Science Publishers Inc.: Enfield, NH, USA, 1997.

91. Subedi, M.; Fullen, M.A.; Hocking, T.J. Agro-environmental project duration and effectiveness in South-East Asia. Outlook Agric. (In Press).

92. McDonald, M., Brown, K., Eds. Issues and Options in the Design of Soil and Water Conservation Projects; School of Agriculture and Forest Sciences Publication Number 17, University of Wales: Bangor, UK, 1999.

93. Saguiguit, G.; Garcia, J.N.; Cramb, R. Promotion of soil conservation measures in The Philippines: The ISF Project in Sitio Domang. In Issues and Options in the Design of Soil and Water Conservation Projects; McDonald, M., Brown, K., Eds.; School of Agriculture and Forest Sciences Publication Number 17, University of Wales: Bangor, UK, 1999.

94. SUAS. Chinese-Swedish Soil Conservation Project 1987-1990: Final Report; Swedish University of Agricultural Sciences (SUAS), International Rural Development Department: Uppsala, Sweden, 1991.

95. AusAID. Targeting poor farmers: Contributions to rural development in Thailand. In Quality Assurance Series No. 16; The Australian Government's Overseas Aid (AusAID) Programme: Canberra, Australia, 1999; Available online: http://www.ausaid.gov.au/publications/pdf/ qas16_thailandfarmers.pdf (accessed September 14, 2009). 
96. TG-HDP. TG-HDP Human Resources Development Study. Thai-German Highland Development Programme. Internal Paper No. 188; Open Database, 1999; Available online: http://www.mekonginfo.org/HDP/Lib.nsf/0/3C32065B4E2AD3998025683400046CE6/\$FILE/F ULLTEXT.html. (accessed September 14, 2009).

97. Dirksen, H. Considerations and Lessons from Implementing the Thai-German Highland Development Program (TG-HDP) in Northern Thailand. Thai-German Highland Development Program (TG-HDP), OpenDatabase, 2001; Available online: http://www.gtz-asia-online.org/ hdp/frame.htm?lib.nsf? (accessed May 14, 2005).

98. Dirksen, H. 18 years of the Thai-German Highland Development Program — has it been a success story? German Technical Co-operation (GTZ), 2002; Available online: http://www.gtz.de/de/ dokumente/en-dirksen-02.pdf. (accessed September 14, 2009).

99. SUAS. Evaluation of the Chinese-Swedish Soil Conservation Co-operation Project, Working Paper No 147; Swedish University of Agricultural Sciences (SUAS), International Rural Development Department: Uppsala, Sweden, 1990.

100. AusAID. Growing rice and protecting forests: An evaluation of three food production projects in SE Asia. In Quality Assurance; The Australian Government's Overseas Aid Programme (AusAID): Canberra, Australia, 1999; Series No. 15.

101. AusAID. Developing rural communities in marginal and rainfed areas: Contributions of agricultural projects in The Philippines. In Quality Assurance; The Australian Government's Overseas Aid Programme (AusAID): Canberra, Australia, 2000; Series No. 23.

102. Riley, J. Indicator quality for multidisciplinary systems. Novart. Fdn. Symp. Series 1999, 220, 178-190.

103. Turkelboom, F., van Keer, K., Eds. Land Management Research for Highland Agriculture in Transition: Research Highlight of the Soil Conservation Project (1989-1995). Mae Jo University, Thailand and Catholic University of Leuven: Leuven, Belgium, 1996.

104. Pretty, J. Social and human capital for sustainable agriculture. In Agroecological Innovation: Increasing Food Production with Participatory Development; Uphoff, N., Ed.; Earthscan: London, UK, 2002.

(C) 2009 by the authors; licensee Molecular Diversity Preservation International, Basel, Switzerland. This article is an open-access article distributed under the terms and conditions of the Creative Commons Attribution license (http://creativecommons.org/licenses/by/3.0/). 